Halyna Horbenko

ORCID iD 0000-0002-5029-0267

PhD in Pedagogical Sciences,

Associate Professor,

Director of the Institute of Journalism,

Borys Grinchenko Kyiv University,

13b Tymoshenko Str., 04212 Kyiv, Ukraine,

h.horbenko@kubg.edu.ua

Yana Fruktova

ORCID iD 0000-0002-8600-5309

PhD in Pedagogical Sciences,

Associate Professor of Journalism and New Media Chair, Institute of Journalism,

Borys Grinchenko Kyiv University, 13b Tymoshenko Str., 04212 Kyiv, Ukraine, y.fruktova@kubg.edu.ua

Oleksandra Hondiul

ORCID iD 0000-0003-2522-8485

Lecturer of Journalism and New Media Chair, Institute of Journalism,

Borys Grinchenko Kyiv University, 13b Tymoshenko Str., 04212 Kyiv, Ukraine, o.hondiul@kubg.edu.ua

\title{
NON-FORMAL EDUCATION OF EDUCATORS IN MEDIA CENTERS OF LEADING EUROPEAN COUNTRIES: EDUCATIONAL AND METHODOLOGICAL ASPECT
}

Media literacy is recognized as a basic, vital skill for European citizens. It must be formed during life, at all stages of personality development. That is why we have chosen the leading European countries such as Finland, Sweden, France, Germany, the United Kingdom and Spain to analyze the current state of media education. Europe should be at the forefront of media literacy, as historically this region of the world has become the cradle of media civilization, a center for coordinating discussions of philosophical, cultural and technical development of the media.

The article deals with the analysis of educational and methodical support of the European system of educators' media education. The importance of media education of educators as the greatest agents of direct educational influence on the younger generation, whose media education is a requirement of the time, is revealed. The need for the development of non-formal and informal media education of educators is identified, as the media component can take place in any lesson and in extracurricular activities. Common components of the organization system of this process (participants, content, forms, methods, tools) are identified and educational and methodological resources are described, which are publicly available and can be useful to educators regardless of country of residence, citizenship or language.

As a result of the research, we made the following conclusions: specialized centers offer a wide range of short-term training courses for teachers of various topics; forms of professional development in media education of teachers are different (distance courses, trainings, seminars, workshops, conferences, educational films, etc.); modern scientific, educational, methodical literature for teachers is available (monographs, professional journals, lesson plans, information packages); non-formal and informal preparation of teachers for media education activities is diverse in content, forms, means and methods, but remains fragmentary, not systematic, which does not allow to solve our issue comprehensively, and therefore it needs further development and critical analysis.

Keywords: curriculum of educators' media education; educational and methodological materials; media centers; non-formal and informal media education of educators. 
https://doi.org/10.28925/1609-8595.2020.4.13

Scientific novelty. For the first time, we attempted to analyze comprehensively the educational and methodological support of non-formal media education of educators in leading European countries in order to develop its components by domestic scientists, taking into account European experience and Ukrainian realities.

Introduction. In 2008, the European Parliament adopted the «Media Literacy in the Digital World Resolution» (European Parliament, 2008), the content of which can be summarized as follows: the media (both traditional and new) is mostly a positive social factor, which, however, requires citizens to own certain specific skills and abilities; media literacy should become a basic element of information consumption policy and cover all categories of people throughout life; media education should be considered as a mandatory part of the curriculum at every stage of school process; it is recommended to include compulsory media education modules in teachers' training curricula.

The following general objectives of the media and information literacy curriculum were developed at the UNESCO Expert Group meeting in June 2008: promotion of understanding of the functions of the media, as well as their capabilities and limitations; development of the necessary independence in the use of media; capacity building, development of rights and responsibilities of citizens in interaction with the media; promotion of access to media and information and communication technologies, their creative and productive use (Wilson, \& Duncan, 2009). In 2009, the European media education project OnAir was launched, which many European countries participated in: Great Britain, Germany, Norway, Poland, Romania and others. The final report of the project states that Europe should be at the forefront of media literacy, as historically this region of the world has become the cradle of media civilization, a center for coordinating discussions of philosophical, cultural and technical development of the media. In December of the same year, the European Parliament approved the introduction of the Media Education component in school standards. This subject should be part of the curriculum at all levels of school education. However, until now «Media Education» in European countries is implemented as a part of school curricula, a separate subject or integrated into subjects that involve the study of native language and culture, social sciences. In any case, the problem of media education of educators remains urgent.

Material and methods. The methodology of our research is based on the scientific, systematic, synergy principles, when the components of the system enhance the effect of each other. We used content analysis of official sites of media centers of leading European countries.

Theoretical background. Justification of the research issue. A program for professional media education of teachers was developed in 2011 under the auspices of UNESCO. The program includes the combination of the concepts of «media» and «information literacy» in «media information literacy» (MIL), outlines the policy and prospects for the introduction of professional training of teachers, basic competencies of teachers that are necessary for the formation of MIL as a professional, teaching methods, algorithms learning through practice, the role of media and information for democratic discourse and individual participation in public life. The manual has two parts: «Curriculum and competency system» is the first, and «Basic and additional Modules» is the second. The authors of the program, C. Wilson, A. Grizzle, R. Tuazon, K. Akyempong and Chi Kim Cheung, identify seven competencies in teacher media literacy: understanding the importance of media and information for democracy; understanding of media content and options for its use; effective and efficient access to information; critical evaluation of information and information sources; use of new and traditional media formats; determining the socio-cultural context of media content; promotion of MIL among students and management of necessary changes (Wilson, Grizzle, 2011, p. 32-36). The second section of the manual reveals the content of eleven modules: «Civic position, freedom of expression and information; access to information, democratic discourse and lifelong learning»; «Understanding the news, media and information ethics»; «Representation in media and information»; «Languages in media and information»; «Advertising»; «New and Traditional media»; «Internet opportunities and challenges»; «Information literacy and library skills»; «Communication, MIL and learning»; «Audience»; «Media in a Global Context». The first nine are offered as mandatory and the last two as optional. This position is in no way argued, and, in our opinion, is wrong, because the characteristics of the target audience determine the technology of development and promotion of media content, the audience determines its success and at the same time feels the social responsibility of media authors. In addition, the role of the media in the global context is more relevant today than ever. Therefore, as theorists and practitioners of media education, we recommend including these topics in educators' training programs.

Content analysis of websites of media educational projects in Europe. We took this opportunity to analyze the state of development of educational and methodological support for non-formal and informal media education of educators in European countries, in particular, Finland, Sweden, France, Germany, Great Britain, Spain and for comparison of Ukraine in recent years. Due to the limited volume of the article, we give some examples to illustrate our analytical conclusions and offer a summary in Table 1.

For example, a number of special research institutes are in Germany, such as the National Institute of Film, Science and Education (Institute fur Film und Bild im 
Educational and methodological resources of media centers in Europe

\begin{tabular}{|l|c|c|c|c|c|c|}
\hline \multicolumn{1}{|c|}{ Country } & $\begin{array}{c}\text { Government } \\
\text { agencies / } \\
\text { NGO / } \\
\text { Media structures }\end{array}$ & $\begin{array}{c}\text { Online } \\
\text { offline training } \\
\text { programs }\end{array}$ & $\begin{array}{c}\text { Thematic } \\
\text { publications }\end{array}$ & $\begin{array}{c}\text { Scientific } \\
\text { results of } \\
\text { research }\end{array}$ & $\begin{array}{c}\text { Lessons' } \\
\text { development, } \\
\text { texts }\end{array}$ & $\begin{array}{c}\text { Audio } \\
\text { and visual } \\
\text { materials }\end{array}$ \\
\hline Finland & $+/+/+$ & $+/+$ & + & + & + & + \\
\hline Sweden & $+/+/+$ & $+/+$ & + & + & + & + \\
\hline Germany & $+/+/+$ & $+/+$ & + & + & + & + \\
\hline Great Britain & $+/+/+$ & $+/+$ & + & + & + & + \\
\hline France & $+/+/+$ & $+/+$ & + & + & + & + \\
\hline Spain & $+/+/+$ & $+/+$ & + & + & + & + \\
\hline
\end{tabular}

Wissenschaft: FWU). It publishes special editions and visual aids for schools (videotapes, brochures, manuals, etc.). Another powerful research center on media education exists in Munich. That is, teachers have the opportunity to be acquainted with the results of recent research in the media sphere. Specialized centers operate successfully, in the Department of Youth Protection of North Saxony (LJS), the State Institute for Advanced Training in School Process and Media Pedagogy (NLI), the Evangelical Media Center in Hanover, the State Media Center in Baden-Württemberg (LMZ).

Today, there are numerous German-language media education websites, where in addition to information about scientific events, thematic competitions, festivals, the latest news on the development of the media sphere. There are various materials for teachers' self-education and lessons, such as Media Pedagogy (Medienpädagogik), Mediaculure-online: Platform for school and extracurricular education (Das portal zur schulischen und ausserschulischen medienbildun).

Numerous professional journals that publish articles that reveal the philosophical, historical, cultural, ethical aspects of media education deserve attention. For example, the online magazine Merz (Merz $\mid$ medien + erziehung ...) is published every two months, and the first issue of 2020 is devoted to the problem of digital violence.

The following media education centers are currently operating successfully in the Great Britain: the Department of Education at the British Film Institute; Center for the Study of Children, Youth and Media, University of London, Film Education Research and Training Center, the English and Media Center; Education Agency of the National Film and Television Agency of Northern Ireland; Media Education Association; Wales Media Education Center; Association for Media Education in Scotland; Film / Media Education Center for Children and Youth (First Light Movies). The latter's website (Into Film) offers: movies, clubs, learning, resources, events, competitions, news and views. Classes are offered for teachers who work with young people aged 5-19 in schools, community groups, such as «Film Directing and Animation in the Classroom», «Development of Media Literacy: A Journey from Still Image to Film».

There are thematic websites, such as «Media literacy versus fake news: critical thinking, resilience and civic participation». «Field Review» (articles on various aspects of media literacy); «Workshop» (Videos and materials from project seminars); «Toolkit» (media literacy resources); «Books», such as Fake News vs. Media Studies: Travels in a False Binary, are site headings. The Data \& Society project website contains original research on current issues, including artificial intelligence and automation, the effects of technology on work and health, and misinformation on the Internet. If necessary and desired, the teacher will find here the most update information for media education lessons.

In France, media education of teachers is usually carried out on special courses. We are impressed by the system of state research and educational centers of media education, which were opened in the $80-90$ s of the last century and still function successfully nowadays. Here is an example of one of them. The CLEMI National Media Education Center (Le centre pour l'education aux médias et a l'information) has both government funding and grants from various foundations. Today, CLEMI, part of the Rseseau Canope network, is responsible for media and information literacy (MIL) in the French education system. The main goal is media education of schoolchildren, research related to media education of students (mainly in the press and the Internet), study the impact of media on the younger generation, increase the media competence of teachers, etc.

CLEMI produces a series of video modules for teachers, illustrating specific cases of media and information education in the first and second stages of school education. Teachers are offered training toolkits for media education lessons, including an information sheet for teachers, a worksheet that allows you to set up 
activities with your students (learning goals, program entries, session progress, extensions), resources that can be used in the classroom (images, video).

Among the novelties on the website we found a manual «Media and information literacy for teachers» (Éducation aux médias et à l'information école collège lycée, 2020), which contains a translation of letters from a pedagogical brochure and pedagogical files created by CLEMI for the Week of Press and Media at School. The manual provides scientific facts, explains new media terms, such as «phishing», «fake», «misinformation» and others, provides examples of media practices on topical issues, such as «CYBER-censorship, a new barrier to freedom of information», «On the border of freedom of speech: self-censorship», materials for lessons on the subject of «Information without borders» for students of different ages, «A round-the-world tour through news pages» for 5-11 years, «Press - a multiuniversal approach?» for 11-14 years students, «Fake news: a multifactorial phenomenon» for 11-18 years students, «Formation of digital identity» and others. The text contains a list of equipment, references to modern sources, forms of student activity (collective, group, individual), algorithm, learning outcomes, content of assessment, questions for discussion, provides detailed guidelines, such as: «Show two or three front pages of the newspaper. Observe and describe them to the whole class, and then list the features they have in common: newspaper name, date, price, titles of different sizes (ask them about their functions: large headlines to get your attention, captions to explain the photo), one or more main headlines, column text, images (photos, cartoons, commercials, etc.)» (Éducation aux médias et à l'information école collège lycée, 2020, 3). This approach allows, in our opinion, to effectively conduct a lesson for schoolteachers who are not specialists in journalism.

In addition to various areas, such as «Cyberjournalism», «Intercultural Dialogue», «Education» and others on the official website of the Portuguese project «Emedus Study» (European Media Literacy), you can find information on «Media Literacy», including teaching materials for teachers. We recommend starting with the monograph «Territories of Media Education» (Los territorios de la educación mediática, Gutiérrez et al., 2015), which contains a description of various experiences in preparing citizens for the critical use of both new and more classical media. This book aims to reflect the path that media education is taking in Spain. The book reflects different views on the social and political role of the media, different methodological orientations and defines the different roles and functions of participants in media education. Teachers will find in this book a wide range of recommendations that will help in the introduction of media education in school practice. The book is not free, but it is useful and recommended by us for purchase, especially for managers and coordinators of media education programs for teachers.
Guide to technology, communication and education for teachers deserves attention. In the «Collection: Media Literacy», the author (Calvo, 2014) emphasizes that the convergence between communicative, educational and technological aspects has led to a large number of changes that affect the professional effectiveness of communicators, teachers, researchers and others. The following relevant topics are offered for consideration: «The role of the educator», «Using the Internet in learning», «Wiki and web journals educational, video games for learning» and many new concepts, approaches, tools and resources. The guide can be ordered for $€ 12$; we took this opportunity and carefully studied its contents. We are sure that it will be useful not only for teachers of schools in Spain, but also in other countries in Europe and the world, including Ukraine.

The site contains announcements of events (conferences, webinars, seminars, etc.) that will be useful to teachers, in particular on informal media education. Among the latest, it can be a series of online seminars «Quality of journalism which free from misinformation». UNESCO organized it on May 4-7, 2020 on media literacy and quality journalism in conjunction with the Communications and Education Department with the participation of the IberoAmerican Association of Educational Television (ATEI), Altaïr Magazine e IcMedia. Each day, a specific topic was presented, including media literacy, for an exchange of views and a roundtable discussion with experts. It is significant that the site presents «MILID Yearbooks», in particular «Media and information literacy for sustainable development»; analytical materials, such as «Perspectives 2015: how teachers see the near future in the classroom» as a scenario of transformations in the Spanish school; experience and teaching and methodological developments of teachers from around the world, in particular, France, Mexico, Colombia.

Finland is one of the countries where media education is widely implemented, in particular through the training of relevant professionals. For example, during the «Media Trainer» project in 2017-2018, the Media Education Association developed a new type of multi-professional training package. The project aimed to meet the acute and growing needs for media education of citizens of all ages, in particular by training new experts. The training program provided high quality, large-scale and thorough professional training of specialists who work with children and youth and plan to carry out media education activities. Schoolteachers across the country could take advantage of this opportunity. «Tame the media» is an another project which just planned, and its purpose is to deepen the understanding of teachers of media education, media and their importance in everyday life of schoolchildren, to acquaint teachers with the principles of phenomenal learning and give them the opportunity to gain their own practical experience. 
The project «Mind Over Media in EU» aims to develop educational materials to support not only Finnish teachers but also other European countries, creating a multilingual online learning platform.

In addition to various forms of non-formal media education, teachers are offered manuals for self-education and educational and methodological developments. For example, a specialized Internet service for teachers «Growing Media» provides teaching materials for media and art education, allows the use of works, tasks and articles by experts of Finnish media artists, a series of videos that can be used in primary and secondary school lessons. The educational materials, along with media education issues, cover topics of multilingualism and cultural diversity.

Numerous manuals are freely available, including «Media in a nutshell» (Mediakasvatus pähkinänkuoressa, 2017) or «From differences to diversity: tools to combat the diversity of media texts» (Palsa, 2019). Their content is focused on teachers working in primary education. And there are many such examples.

Discussions and conclusions. We analyzed the experience of professional media education of teachers in leading European countries and made the following conclusions: schoolchildren media education is declared and can be implemented as a separate subject, optional course, be integrated into other subjects; teachers remain the main actors in the introduction of media education in school practice; teachers receive media education knowledge mainly in the context of nonformal and informal education; specialized centers offer a wide range of short-term training courses for teachers of various topics; forms of professional development in media education of teachers are different (distance courses, trainings, seminars, workshops, conferences, educational films, etc.); modern scientific, educational, methodical literature for teachers is available (monographs, professional journals, lesson plans, information packages); non-formal and informal preparation of teachers for media education activities is diverse in content, forms, means and methods, but remains fragmentary, not systematic, which does not allow to comprehensively solve the problem; experts from different countries have developed common approaches to media education of teachers, in particular the UNESCO program, but they are of a recommendatory nature, although they could be recognized at the level of relevant commissions of the European Parliament as invariant for European countries due to their scientific validity and practical significance; available international and state legal documents allow to substantiate the findings and regulate the activities of media centers, and scientific and educational manuals allow to select the modern content of media education of teachers as a specific target audience.

The results of scientific research allowed us to begin the process of developing and testing programs for teachers at the Media School of Borys Grinchenko Kyiv University in accordance with international standards and recommendations. As of today, 12 author's trainings on «Media Competence» (thematic units: «Media Psychology», «Media Security», «Media Production» and «Media Technologies») were attended by 96 teachers from different regions of Ukraine in November 2019, 2020 - 44 school teachers from all over Ukraine were interested in the online program during pandemic.

\section{References}

Calvo, S. T. (2014). Guía de tecnología, comunicación y educación para profesores: Preguntas y respuestas. Media Literacy. Pérez Tornero, J. M. \& Tejedor, S. (Eds.) UOC.

European Parliament Resolution of 16 December 2008 on Media Literacy in a Digital World (2008). European Parliament. https://www.europarl.europa.eu/sides/getDoc.do?pubRef=-//EP//TEXT+TA+P6-TA-2008-0598 $+0+\mathrm{DOC}+\mathrm{XML}+\mathrm{V} 0 / / \mathrm{EN}$

Data $\mathcal{E}$ Society. https://datasociety.net/

Éducation aux médias et à l'information. École, college, lycée (2020). https://www.clemi.fr/fileadmin/user_upload/ Brochures/EMI_2020/CLEMI_Brochure2020_web.pdf

Emedus Study. European Media Literacy. http://www.cecs.uminho.pt/projetos/emedus-european-media-literacyeducation-study/

Fez declaration on media and information literacy (2011). United Nations Educational, Scientific and Cultural Organization (UNESCO). http://www.unesco.org/new/fileadmin/MULTIMEDIA/HQ/CI/CI/pdf/news/ Fez\% 20Declaration.pdf

Gutiérrez, A. F., Rodríguez-Hoyos, C., Pérez Tornero, J. M. (2015). Los territorios de la educación mediática. Experiencias en contextos educativos. UOC.

Into Film. https://www.intofilm.org/training

Mediakasvatus pähkinänkuoressa (2017). Mediakasvatusseuran julkaisuja, 3. https://mediakasvatus.fi/wpcontent/uploads/2019/11/SELKO-mediakasvatus-p\%C3\%A4hkin\%C3\%A4nkuoressa.pdf

Le centre pour l'education aux médias et a l'information. https://www.clemi.fr/

Mediaculure-online: Platform for school and extracurricular education (Das portal zur schulischen und ausserschulischen medienbildun). https://www.lmz-bw.de/medien-und-bildung/mediaculture-online/

Media literacy versus fake news: critical thinking, resilience and civic participation. http://mlfn.cemp.ac.uk/ 
Medienpädagogik. https://www.bpb.de/lernen/digitale-bildung/medienpaedagogik/

Merz | medien + erziehung ... https://www.merz-zeitschrift.de/

Mind Over Media in EU. https://propaganda.mediaeducationlab.com/

Palsa, L. (2019). Tajuukskukaan - mitä mediakasvatuksella tavoitellaan. https://kansanvalistusseura.fi/wpcontent/uploads/2018/05/Palsa_Kesyt\%C3\%A4-media_Tajuuks-kukaan.pdf

Wilson, C., \& Duncan, B. (2009). Implementing Mandates in Media Education: The Ontario Experience. In FrauMeigs, D. \& Torrent, J., (Eds.) Mapping Media Education Policies in the World (pp. 127-140). UN-Alliance of Civilizations; Grupo Comunicar.

Wilson, C., Grizzle, A. et al. (2011). Media and Information Curriculum for Teachers. UNESCO.

\section{НЕФОРМАЛЬНА ОСВІТА ПЕДАГОГІВ У МЕДІАЦЕНТРАХ ПРОВІДНИХ КРАЇН ЄВРОПИ: НАВЧАЛЬНО-МЕТОДИЧНИЙ АСПЕКТ}

Горбенко Галина, кандидат педагогічних наук, доцент, директор Інституту журналістики, Київський університет імені Бориса Грінченка, вул. Тимошенка, 13-б, 04212 Київ, Україна, h.horbenko@kubg.edu.ua

Фруктова Яна, кандидат педагогічних наук, доцент кафедри журналістики та нових медіа Інституту журналістики,

Київський університет імені Бориса Грінченка, вул. Тимошенка, 13-б, 04212 Київ, Україна, y.fruktova@kubg.edu.ua

Гондюл Олександра,

викладач кафедри журналістики та нових медіа Інституту журналістики,

Київський університет імені Бориса Грінченка, вул. Тимошенка, 13-б, 04212 Київ, Україна, o.hondiul@kubg.edu.ua

Медіаінформаційнаграмотністьвизнанабазовою,життєвонеобхідноюдлягромадян Європи. Вонамає формуватися протягом життя, на всіх етапах становлення особистості. Свропа на сьогодні перебуває на передовій формування медіаграмотності, оскільки історично склалося так, що саме цей регіон світу став колискою медійної иивілізації, центром для координацї дискусій філософського, культурологічного та технічного розвитку засобів масової інформації. Саме тому ми обрали провідні країни регіону для аналізу сучасного стану медіаосвіти, такі, як Фінляндія, Швеція, Франиія, Німеччина, Велика Британія та Іспанія. Статтю присвячено аналізу навчально-методичного забезпечення європейської системи медіаосвіти педагогів. Розкрито значення медіаосвіти саме педагогів як найбільших агентів безпосереднвого виховного впливу на представників молодого покоління, медіаосвіта якихє вимогою часу. Визначено необхідність розвитку саме неформальної та інформальної медіаосвіти вчителів, оскільки медіакомпонент може мати місце на будь-якому урочі та в позаурочній діяльності. Виявлено спільні компоненти системи організації цього процесу (учасники, зміст, форми, методи, засоби) та описано навчально-методичні ресурси, які є загальнодоступними і можуть стати в нагоді педагогам незалежно від країни проживання, громадянства чи мови спілкування. У результаті дослідження зроблено наступні висновки: спеціалізовані центри пропонують широкий спектр короткотривалих навчальних курсів для педагогів різноманітної тематики; форми підвищення кваліфікації з медіаосвіти педагогів різноманітні (дистанційні курси, тренінги, семінари, воркщопи, конференції, навчальні фільми тощо); існує доступна для широкого загалу сучасна наукова, навчальна, методична література для вчителя (монографіі, фахові журнали, розробки уроків, інформачійні пакети); неформальна та інформальна підготовка педагогів до медіаосвітньої діяльності різноманітна за змістом, формами, засобами та методами, проте залишається фрагментарною, не системною, що не дозволяє комплексно розв'язувати окреслену нами проблему, а отже потребує подальшої розробки та критичного налізу.

Ключові слова: медіацентри; навчальна програма медіаосвіти педагогів; неформальна та інформальна медіаосвіта педагогів; навчально-методичні матеріали. 


\section{НЕФОРМАЛЬНОЕ ОБРАЗОВАНИЕ ПЕДАГОГОВ В МЕДИАЦЕНТРАХ ВЕДУЩИХ СТРАН ЕВРОПЫ: УЧЕБНО-МЕТОДИЧЕСКИЙ АСПЕКТ}

Горбенко Галина, кандидат педагогических наук, доцент, директор Института журналистики,

Киевский университет имени Бориса Гринченко, ул. Тимошенко, 13-б, 04212 Киев, Украина, h.horbenko@kubg.edu.ua

Фруктова Яна, кандидат педагогических наук, доцент, доцент кафедры журналистики и новых медиа Института журналистики,

Киевский университет имени Бориса Гринченко, ул. Тимошенко, 13-б, 04212 Киев, Украина, y.fruktova@kubg.edu.ua

Гондюл Александра,

преподаватель кафедры журналистики и новых медиа Института журналистики,

Киевский университет имени Бориса Гринченко, ул. Тимошенко, 13-б, 04212 Киев, Украина, o.hondiul@kubg.edu.ua

Медиаинформационная грамотность признана базовой, жизненно необходимой для граждан Европы. Она должна формироваться в течение жизни, на всех этапах становления личности. Европа сегодня находится на передовой формирования медиаграмотности, поскольку исторически сложилось так, что именно этот регион мира стал кольбелью медийной цивилизации, иентром координации дискуссий философского, культурологического и технического развития средств массовой информации. Именно поэтому мы выбрали ведущие страны региона для анализа современного состояния медиаобразования, такие, как Финляндия, Швеция, Франция, Германия, Великобритания и Испания. Статья посвящена анализу учебно-методического обеспечения европейской системы медиаобразования педагогов как крупнейших агентов непосредственного воспитательного воздействия на представителей молодого поколения, медиаобразование которых является требованием времени. Определена необходимость развития именно неформального и информального медиаобразования учителей, поскольку медиакомпонент может иметь место на любом уроке и во внеурочной деятельности. Выявлены общие компоненты системы организации этого прочесса (участники, содержание, формы, методы, средства) и описаны учебно-методические ресурсы, которые являются общедоступными и могут пригодиться педагогам независимо от страны проживания, гражданства или языка общения. В результате исследования сделаны следуюшие выводы: специализированные иентры предлагают широкий спектр краткосрочных учебных курсов для педагогов различной тематики; формы повышения квалификации по медиаобразованию педагогов разнообразны (дистаниионные курсы, тренинги, семинары, ворк-шопы, конференции, учебные фильмы и т.д.); существует доступная для широкой общественности современная научная, учебная, методическая литература для учителя (монографии, профессиональные журналы, разработки уроков, информачионные пакеты); неформальная и информальная подготовка педагогов $\kappa$ медиаобразовательной деятельности разнообразна по содержанию, формам, средствами и методами, однако она остается фрагментарной, не системной, что не позволяет комплексно решать очерченную нами проблему, а следовательно, нуждается в дальнейшей разработке и критическом анализе.

Ключевые слова:медиащентры; неформальное и информальноемедиаобразование педагогов; учебная программа медиаобразования педагогов; учебно-методические материалы.

Article was: Received 28.10.2020 Accepted 26.11.2020 